\title{
Self-initiated Photocatalytic Polymerization of Tough and Flexible Polyacrylamide Hydrogel/Polymeric Semiconductor $\mathrm{C}_{3} \mathrm{~N}_{4}$ Composites
}

\author{
Suphatchaya Lamkhao* and Chamnan Randorn
}

\author{
Department of Chemistry, Faculty of Science, Chiang Mai University, Thailand, 50200 \\ *l.k.rattikarn@gmail.com
}

\begin{abstract}
Polyacrylamide (PAM) $/ \mathrm{g}-\mathrm{C}_{3} \mathrm{~N}_{4}$ composite materials were prepared by the self-initiation of $\mathrm{C}_{3} \mathrm{~N}_{4}$ via its photocatalytic activity. Radical species were produced during illumination of g- $\mathrm{C}_{3} \mathrm{~N}_{4}$ and can initiate the formation of the $\mathrm{PAM} / \mathrm{C}_{3} \mathrm{~N}_{4}$ composite. The effect of charcoal composited to $\mathrm{C}_{3} \mathrm{~N}_{4}$ was also investigated. The physical properties of the PAM/g- $\mathrm{C}_{3} \mathrm{~N}_{4}$ and $\mathrm{PAM} / \mathrm{g}-\mathrm{C}_{3} \mathrm{~N}_{4}$-charcoal composite materials were analyzed using SEM technique. Photocatalytic reduction of chromium (VI) to chromium (III) was validated using the composites.
\end{abstract}

Keywords: Polyacrylamide, $\mathrm{g}-\mathrm{C}_{3} \mathrm{~N}_{4}, \mathrm{Chromium}(\mathrm{VI})$ reduction, Photocatalysis

\section{Introduction}

Hydrogels are a 3D crosslinked polymeric material that contains a hydrophilic group that can swell and retain a large amount of water or biological fluid within the structure without dissolving [1]. This ability to swell under biological conditions makes hydrogels an ideal material for biomedical applications, such as tissue engineering $[2,3]$ and drug delivery [4,5]. Hydrogels can be synthesized by synthetic polymers or natural polymers. One of the recently used synthetic polymers is polyacrylamide (PAM), which is a nontoxic, biologically inert compound with a long chain length. PAM has a capacity for preserving its shape and mechanical strength, with conveniently adjustable mechanical, chemical and biophysical properties, allowing for its wide use in tissue engineering applications. Hydrogels can be synthesized via different polymerization methods [6]. Radical polymerization is one of the most attractive methods to prepare hydrogels because of their low cost and convenience. Free radical polymerization is a method of polymerization where a polymer forms as the successive addition of a free radical to the monomer $[7,8]$.

Radicals generated during photocatalytic processes play an important role in the photocatalytic reaction. Therefore, these radicals might be a promising candidate as a photo-initiator for utilization in radical polymerization processes $[9,10]$. The photo-initiator is one type of initiator in radical polymerization. It normally uses metal iodides, metal alkyls, peroxide and azo compounds as initiators. Recently, semiconductors have been found to generate radicals using a heterogeneous photocatalysis process. It has gradually gained attention but is rarely used in the polymerization process. In fact, not only semiconductors can generate radicals, but they can also improve the mechanical properties of the synthesized polymer. Polyacrylamide hydrogels have used semiconductors, such as $\mathrm{TiO}_{2}, \mathrm{ZnO}, \mathrm{SnO}_{2}, \mathrm{CdSe}$ and $\mathrm{Fe}_{2} \mathrm{O}_{3}$, as initiators and found that the hydrogel exhibit excellent mechanical strength and high elasticity $[11,12]$.

Recently the $\mathrm{g}-\mathrm{C}_{3} \mathrm{~N}_{4}$ photocatalyst has been extensively studied because it is active under visible light $[13,14]$. The photoactivity of the $\mathrm{g}-\mathrm{C}_{3} \mathrm{~N}_{4}$ catalyst has been examined for several purposes, including $\mathrm{NO}_{\mathrm{x}}$ photocatalytic activity under UV and visible light irradiation $[15,16]$, water splitting, and $\mathrm{CO}_{2}$ photoreduction [13]. Moreover, the band gap

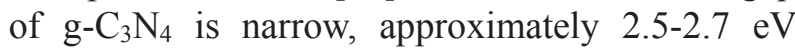
$[13,14]$, and visible light can be utilized to activate the catalyst. $\mathrm{PAM} / \mathrm{g}-\mathrm{C}_{3} \mathrm{~N}_{4}$ composite materials might be of interest for several applications, e.g. 
provide the transport of analytes through interparticle channels, gel density controllable and enhance the efficiency of protein separation in gel electrophoresis. Moreover, g- $\mathrm{C}_{3} \mathrm{~N}_{4}$ modified with charcoal may also improve some properties of the hydrogel because charcoal is widely known to be a good absorber. A high surface area of charcoal would benefit the adsorption stage of the photocatalytic process. Charcoal can adsorb almost all reactants, such as water-soluble ions, organic compounds, inorganic compounds and heavy metals [17], which provides more active sites for the reaction between photo generated active species and reactants.

This work reports the novel fabrication of $\mathrm{PAM} / \mathrm{g}-\mathrm{C}_{3} \mathrm{~N}_{4}$ and $\mathrm{PAM} / \mathrm{g}-\mathrm{C}_{3} \mathrm{~N}_{4}$-charcoal composite hydrogel via a self-initiator of photopolymerization. The strong and good distribution of g- $\mathrm{C}_{3} \mathrm{~N}_{4}$ in hydrogel was expected from this method, making it advantageous over other methods. The structure morphology and functional group of these self-initiated composite hydrogels were investigated. The photocatalytic activities were investigated by photoreduction of chromium (VI) to chromium (III). The photoreduction reaction has environmental significance because chromium (VI) is a common pollutant that is highly toxic to human health [18-20].

\section{Experimental}

\subsection{Materials}

Melamine was purchased from Sigma Aldrich (99\%). Acylamide and $N, N$ '-methylenebis acrylamide used for synthesis were purchased from Merck. Ammonium persulphate was purchased from Calbiochem.

\subsection{Preparation of $g-\mathrm{C}_{3} \mathrm{~N}_{4}$ and $\mathrm{g}-\mathrm{C}_{3} \mathrm{~N}_{4}$-charcoal}

g- $\mathrm{C}_{3} \mathrm{~N}_{4}$ was prepared by a condensation of melamine; whereas, $\mathrm{g}-\mathrm{C}_{3} \mathrm{~N}_{4}$-charcoal was prepared via a one-step thermal condensation of melamine and charcoal $(100: 4, \mathrm{wt} / \mathrm{wt})$. Calcination of the powders was performed at $500{ }^{\circ} \mathrm{C}$ under air atmospheres for $2 \mathrm{hr}$. with a heating and cooling rate of $10^{\circ} \mathrm{C} / \mathrm{min}$, respectively.

\subsection{Preparation of self-initiated $\mathrm{PAM} / \mathrm{g}-\mathrm{C}_{3} \mathrm{~N}_{4}$ and} $\mathrm{PAM} / \mathrm{g}-\mathrm{C}_{3} \mathrm{~N}_{4}$-charcoal composite hydrogel

The suspension of $\mathrm{g}-\mathrm{C}_{3} \mathrm{~N}_{4}$ or $\mathrm{g}-\mathrm{C}_{3} \mathrm{~N}_{4}$-charcoal in aqueous solution of acrylamide and $N, N^{\prime}-$ methylenebisacrylamide was similar to the conventional method but without initiators. Next, the suspension was placed into a 15-watt UV-LED homemade reactor and left until gelation occurred. The synthesized products were washed with water and freeze dried for a day for further characterization.

XRD data were collected using a Rigaku Mini Flex II X-ray diffractometer. The specific surface area of the powder samples was measured by nitrogen adsorption at $77 \mathrm{~K}$ using the BrunauerEmmett-Teller (BET) method (Micromeritics TriStar II). Scanning electron microscopy and transmission electron microscopy were performed using a JEOL JSM-6335F microscope and JEOL JEM-2010 electron microscope, respectively.

\subsection{Evaluation of photocatalytic activity}

The photocatalytic ability of PAM/g- $\mathrm{C}_{3} \mathrm{~N}_{4}$ and $\mathrm{PAM} / \mathrm{g}-\mathrm{C}_{3} \mathrm{~N}_{4}$-charcoal under visible light were evaluated by suspending the composites in $50 \mathrm{~mL}$ of $\mathrm{K}_{2} \mathrm{Cr}_{2} \mathrm{O}_{7}$ solution. The suspension was first kept in the dark for 24 hours to reach an adsorption equilibrium at room temperature. Then, the suspension was illuminated with a homemade 30 watts visible LED lamp. A change in absorption of $\mathrm{Cr}^{6+}$ diphenylcarbazide complex measured at 542 $\mathrm{nm}$ in acid solution was monitored every 1 hour using a UV-Vis spectrophotometer.

\section{Results and discussion}

Self-initiated photocatalytic polymerization reaction highly depends on surface area, particle size and morphology of the photocatalysts. Table 1 shows a BET surface area and $\mathrm{C}: \mathrm{N}$ ratio of the synthesized g- $\mathrm{C}_{3} \mathrm{~N}_{4}$ and g- $\mathrm{C}_{3} \mathrm{~N}_{4}$-charcoal. The BET surface area of the powders plays a major role for a radical generation by photocatalytic activity. It was found that $\mathrm{g}-\mathrm{C}_{3} \mathrm{~N}_{4}$ and $\mathrm{g}-\mathrm{C}_{3} \mathrm{~N}_{4}$-charcoal showed a moderate surface area. The $\mathrm{g}-\mathrm{C}_{3} \mathrm{~N}_{4}$-charcoal had a little bit higher surface area than naked $\mathrm{g}_{-} \mathrm{C}_{3} \mathrm{~N}_{4}$. This is likely due to a higher inner porous area of charcoal produced under an oxidizing air atmosphere [9]. The $\mathrm{C}: \mathrm{N}$ ratio of $\mathrm{g}-\mathrm{C}_{3} \mathrm{~N}_{4}$ obtained by EDS was consistent with those of other works $[19,20]$. Whereas $\mathrm{C}: \mathrm{N}$ ratio of $\mathrm{g}-\mathrm{C}_{3} \mathrm{~N}_{4}$-charcoal samples showed higher content of carbon and lesser content of oxygen, indicating a composite of $\mathrm{g}-\mathrm{C}_{3} \mathrm{~N}_{4}$ and charcoal.

SEM images of charcoal, g- $\mathrm{C}_{3} \mathrm{~N}_{4}$ and $\mathrm{g}_{-} \mathrm{C}_{3} \mathrm{~N}_{4-}$ charcoal are shown in Fig. 1. Smooth surface agglomeration of charcoal and rough surface with some agglomeration of $\mathrm{g}-\mathrm{C}_{3} \mathrm{~N}_{4}$ were observed. The characteristic surface of charcoal and $g-\mathrm{C}_{3} \mathrm{~N}_{4}$ are useful in an analysis of the composite of $\mathrm{g}_{-} \mathrm{C}_{3} \mathrm{~N}_{4}$ charcoal. Charcoal has a smooth surface because of 
the agglomeration of individual amorphous powders; whereas, $\mathrm{g}-\mathrm{C}_{3} \mathrm{~N}_{4}$ is a graphene-like sheet, so that a rough surface was observed.

Table1. The BET surface area and C:N:O ratio of the synthesized powders

\begin{tabular}{|c|c|c|c|c|}
\hline \multirow[t]{2}{*}{ Material } & \multirow{2}{*}{$\begin{array}{l}\text { BET } \\
\text { surface } \\
\operatorname{area}\left(\mathrm{m}^{2} / \mathrm{g}\right)\end{array}$} & \multicolumn{3}{|c|}{ EDS of Weight \% } \\
\hline & & $\mathbf{C}$ & $\mathbf{N}$ & $\mathbf{O}$ \\
\hline $\mathrm{g}-\mathrm{C}_{3} \mathrm{~N}_{4}$ & 44.92 & 31.13 & 59.44 & 9.42 \\
\hline $\begin{array}{l}\mathrm{g}-\mathrm{C}_{3} \mathrm{~N}_{4^{-}} \\
\text {charcoal }\end{array}$ & 46.25 & 44.74 & 53.79 & 1.47 \\
\hline
\end{tabular}

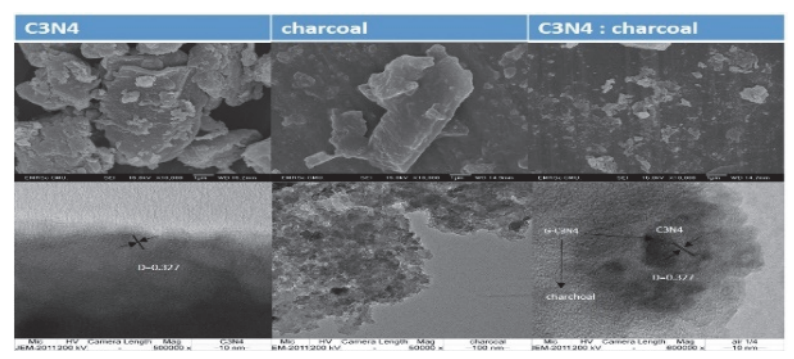

Fig. 1. SEM and HRTEM images of charcoal, $\mathrm{g}-\mathrm{C}_{3} \mathrm{~N}_{4}$ and g- $\mathrm{C}_{3} \mathrm{~N}_{4}$-charcoal.

The morphology of $\mathrm{g}-\mathrm{C}_{3} \mathrm{~N}_{4}$-charcoal (100:4, $\mathrm{wt} / \mathrm{wt}$ ) calcined under air atmosphere exhibited small separated flake morphology; this is possibly due to the moderate oxidation of charcoal. HRTEM images confirmed an existence of $g-\mathrm{C}_{3} \mathrm{~N}_{4}$ embedded into charcoal. D-spacing of g- $\mathrm{C}_{3} \mathrm{~N}_{4}$ in $\mathrm{g}_{-} \mathrm{C}_{3} \mathrm{~N}_{4}$ and g$\mathrm{C}_{3} \mathrm{~N}_{4}$-charcoal were clearly seen.

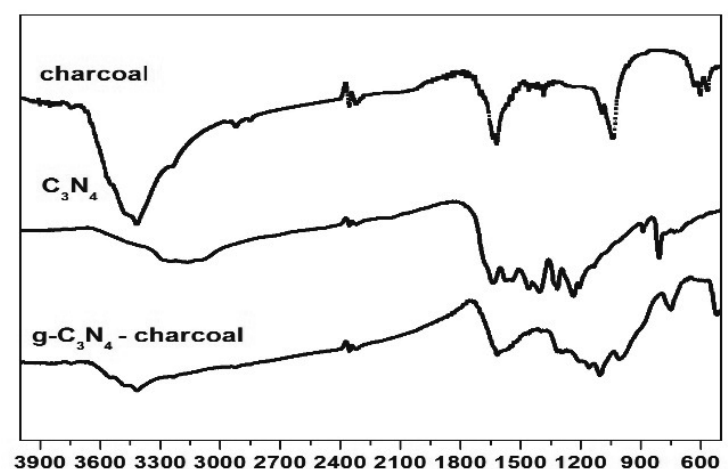

Fig. 2. FT-IR spectra of charcoal, $\mathrm{g}-\mathrm{C}_{3} \mathrm{~N}_{4}$ and $\mathrm{g}-\mathrm{C}_{3} \mathrm{~N}_{4-}$ charcoal.

Figure 2 shows the IR vibrational frequencies of charcoal, g- $\mathrm{C}_{3} \mathrm{~N}_{4}$ and $\mathrm{g}-\mathrm{C}_{3} \mathrm{~N}_{4}$-charcoal. The IR spectra exhibited a characteristic band at 1,650-
$1,500 \mathrm{~cm}^{-1}$, which corresponds to the $\mathrm{C}=\mathrm{C}$ and $\mathrm{C}-\mathrm{O}$ functional groups of charcoal. The $\mathrm{g}-\mathrm{C}_{3} \mathrm{~N}_{4}$ charcoal sample showed a contribution band of similar several fingerprint bands of $\mathrm{g}_{-} \mathrm{C}_{3} \mathrm{~N}_{4}$ and charcoal. Sharp bands at approximately $820 \mathrm{~cm}^{-1}$ was corresponded to triazine units [15].

Figure 3 shows the SEM images of the PAM/g$\mathrm{C}_{3} \mathrm{~N}_{4}$ prepared by self-inititated photocatalytic polymerization. It was found that the self-initiated $\mathrm{PAM} / \mathrm{g}-\mathrm{C}_{3} \mathrm{~N}_{4}$ had a good distribution of $\mathrm{g}-\mathrm{C}_{3} \mathrm{~N}_{4}$ into the hydrogel. The distribution is attributed to the radical produced at the surface of g-C $3 \mathrm{~N} 4$. Therefore, polymerization hydrogel would have happened at the surface of $\mathrm{g}-\mathrm{C}_{3} \mathrm{~N}_{4}$. This finding may contribute to the strong and tough of the composite hydrogel because $\mathrm{g}_{-} \mathrm{C}_{3} \mathrm{~N}_{4}$ was distributed throughout the hydrogel. On the other hand, PAM/ g- $\mathrm{C}_{3} \mathrm{~N}_{4}$ composite hydrogel, prepared by conventional method using ammonium persulfate as initiator, have obvious boundary lines between the PAM hydrogel and $\mathrm{g}-\mathrm{C}_{3} \mathrm{~N}_{4}$. However, swelling ratio of the PAM $/ \mathrm{g}-\mathrm{C}_{3} \mathrm{~N}_{4}$ composite hydrogel was rather smaller than the PAM hydrogel because the interconnect of $\mathrm{g}-\mathrm{C}_{3} \mathrm{~N}_{4}$ throughout the hydrogel inhibit a swelling of the hydrogel, which a mechanism may be proposed as shown in Fig. 4.

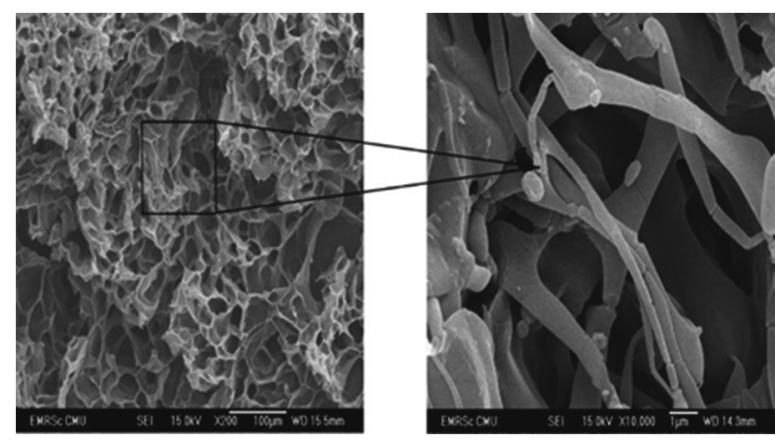

Fig. 3. SEM images of PAM/g- $\mathrm{C}_{3} \mathrm{~N}_{4}$.
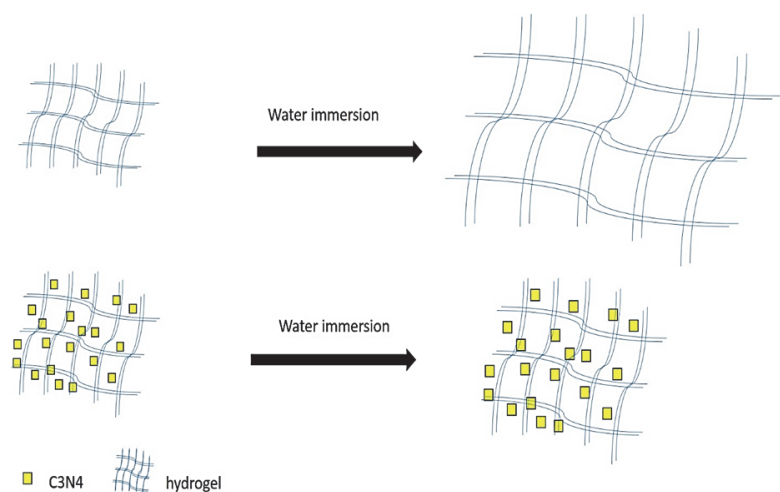

Fig. 4. The proposed mechanism of swelling ratio of the hydrogels. 
Photocatalytic reduction of chromium (VI) to chromium (III) was also investigated.

The separation of a photoactivity effect from an adsorption effect was measured using an adsorption experiments for $24 \mathrm{hrs}$ (Fig. 5). It was found that percent $\mathrm{Cr}$ (VI) sorption increases when using PAM, $\mathrm{PAM} / \mathrm{g}-\mathrm{C}_{3} \mathrm{~N}_{4}$ and $\mathrm{PAM} / \mathrm{g}-\mathrm{C}_{3} \mathrm{~N}_{4}$-charcoal as adsorbent, respectively. $\mathrm{g}-\mathrm{C}_{3} \mathrm{~N}_{4}$ seems to have adsorption capacity for chromium (VI) higher than naked PAM. However, existence of charcoal on g$\mathrm{C}_{3} \mathrm{~N}_{4}$ provide the highest adsorption capacity. Chromium (VI) adsorption was in equilibrium after keeping the suspension in the dark for $18 \mathrm{hrs}$.

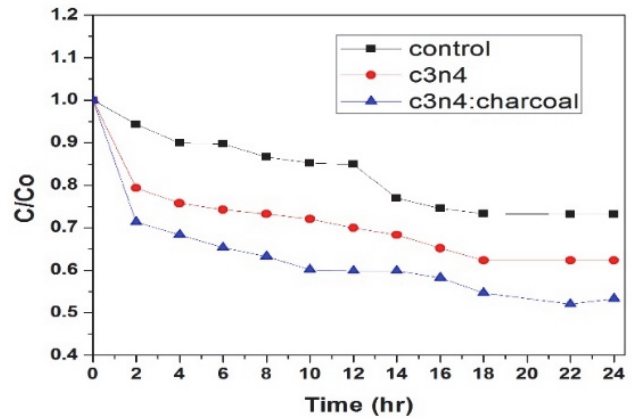

Fig. 5. Adsorption capacity of chromium (VI).

Photocatalytic reduction of chromium (VI) to chromium (III) was evaluated after an equilibrium of adsorption as shown in Fig. 6. The naked PAM showed neglect activity. The photoactivity of g$\mathrm{C}_{3} \mathrm{~N}_{4}$ was moderate because of the narrow band gap energy of $\mathrm{g}-\mathrm{C}_{3} \mathrm{~N}_{4}$, which facilitated $\mathrm{e}^{-}$-hole pairs recombination. The hydrogel with higher surface area, $\quad \mathrm{PAM} / \mathrm{g}-\mathrm{C}_{3} \mathrm{~N}_{4}$-charcoal enhanced photoactivity; this confirms the effect of an increased surface area. Moreover, this is possibly due to the electron transfer between the conduction band of $\mathrm{g}-\mathrm{C}_{3} \mathrm{~N}_{4}$ to charcoal is beneficial in the suppression of $\mathrm{e}^{-}-\mathrm{h}^{+}$pair recombination.

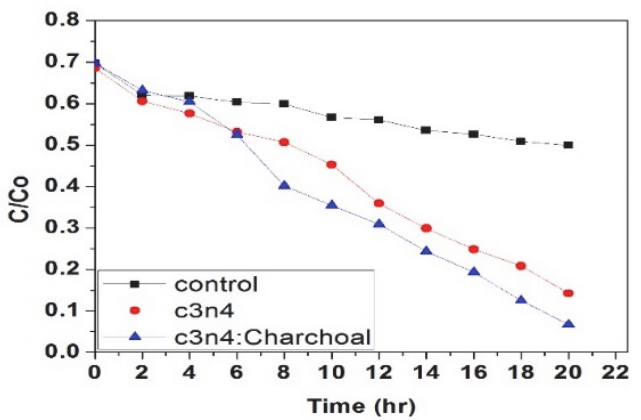

Fig. 6. Photocatalytic reduction of chromium (VI) to chromium (III).

\section{Conclusion}

A novel fabrication of PAM/g- $\mathrm{C}_{3} \mathrm{~N}_{4}$ and $\mathrm{PAM} / \mathrm{g}$ $\mathrm{C}_{3} \mathrm{~N}_{4}$-charcoal composite hydrogel is reported using a one-step method. Composite materials were successfully prepared using photoactivity of g$\mathrm{C}_{3} \mathrm{~N}_{4}$. The photocatalytic reduction activities chromium (VI) to chromium (III) were investigated. The $\mathrm{PAM} / \mathrm{g}-\mathrm{C}_{3} \mathrm{~N}_{4}$-charcoal showed good photoactivity, consisting with the hypothesis that charcoal acts as electron transfer surface.

\section{Acknowledgement}

The authors would like to acknowledge the Thailand research Fund (TRF), the Center for Innovation in Chemistry (PERCH-CIC), Commission on Higher Education, Ministry of Education and Faculty of Science, Chiang Mai University for financial support.

\section{References}

1. E. M. Ahmed, J. Adv. Res., 6 (2015) 105.

2. J. Zhu and E. R. Marchant, Expert Rev. Med. Devices, 8, (2011) 607.

3. K. Y. Lee and J. D. Mooney, Chem. Rev., 7 (2001) 101.

4. J. L. Drury and J. D. Mooney, Biomaterials, 24 (2003) 4337.

5. M. Hamidi, A. Azadi, and P. Rafiei, Adv. Drug Deliv. Rev., 60 (2008) 1638.

6. R. T. Hoare and S. D. Kohane, J. Polym. Sci. A: Polym. Chem., 49 (2008) 1993.

7. T. Ashutosh and T. Atul, "Nanomaterials in Drug Delivery, Imaging, and Tissue Engineering”, Newgersy and Salem, Canada (2001) p 22.

8. N. Das, Int. J. Pharm. Sci., 5 (2013) 112.

9. G. Odian, "Principles of polymerization", 4th Ed. Wiley-e., NewYork, (2004) p198.

10. Y. Yagci, S. Jockusch, and J. N. Turro, Macromolecules, 43 (2010) 6245.

11. A. Mills and L. S. Hunte, J. Photochem. Photobiol. A: Chem., 108 (1997) 1.

12. K. Nakata and A. Fujishima, J. Photochem. Photobiol. C: Photochem. Rev., 13 (2012) 169.

13. D. Zhang, J. Yang, S. Bao, Q.Wu, and Q. Wang, Sci. Rep., 3 (2013) 1399.

14. C. Liao, Q. Wu, T. Su, D. Zhang, Q. Wu, and Q. Wang, ACS Appl. Mater. Interfaces, 6 (2014) 1356.

15. S. Ye, R. Wang, M.-Z. Wu, and Y.-P. Yuan, Appl. Surf. Sci., 358A (2015) 15.

16. Y. Zhang, Q. Pan, G. Chai, M. Liang, G. Dong, Q. Zhang, and J. Qiu, Sci. Rep., 3 (2013) 1943.

17. I. Papailias, T. Giannakopoulou, N. Todorova, D. 
Demotikali, T. Vaimakis, and C. Trapalis, Appl. Surf. Sci., 358A (2015) 278.

18. Y. Wang, X. Wang, X. Wang, M. Liu, L. Yang, Z. Wu, S. Xia, and J. Zhao, J. Colloid Interface Sci., 414 (2012) 1.
19. F. Dong, Y. Li, Z. Wang, and W.-K. Ho, Appl. Surf. Sci., 358A (2015) 393.

20. L. B. Khalil, W. E. Mourad, and M. W. Rophael Appl. Catal. B, 17 (1998) 267. 